\title{
Magnetic Properties of Sr-Zn-W-Type Ferrite Powders and Application to a Torque Limiter of Bonded Magnets Prepared by Using These Powders
}

\author{
H. Yamamoto, Y. Koizumi, and H. Yamaguchi \\ School of Science and Technology, Meiji Univ., 1-1-1 Higashimita, Tama-ku, Kawasaki 214-8571, Japan
}

\begin{abstract}
An experiment was carried out to examine the application of an Sr-Zn-W-type hexagonal ferrite bonded magnet as a hysteresis bonded magnet in a non-contact-type torque limiter using a magnet. The magnetic properties of $\mathrm{Sr}-\mathrm{Zn}-\mathrm{W}$-type hexagonal powders ware first examined in order to prepare a bonded magnet. The preparation conditions for a typical sample were as follows: chemical analysis composition, $\mathrm{Sr}^{2+}{ }_{0.93} \mathrm{Zn}^{2+}{ }_{0.93} \mathrm{Fe}^{2+}{ }_{1.02} \mathrm{Fe}^{3+}{ }_{16.07} \mathrm{O}_{27}$; reaction sintering condition, $1300^{\circ} \mathrm{C} \times 4.0 \mathrm{~h}$ in air; average particle size after pulverizing, $0.85 \mu \mathrm{m}$. The magnetic properties of Sr-Zn-W-type hexagonal ferrite powders are $\sigma_{\mathrm{s}}=95.5 \times 10^{-6} \mathrm{~Wb} \cdot \mathrm{m} / \mathrm{kg}, \mathrm{H}_{\mathrm{cJ}}=60.5 \mathrm{kA} / \mathrm{m}$. Next, an injection molding bonded as a hysteresis bonded magnet was prepared by using these powders and Sr-M-type ferrite powders. Non-contact-type torque limiters were made experimentally by using these bonded magnets. The torque value of a torque limiter prepared from an $\mathrm{Sr}-\mathrm{Zn}-\mathrm{W}$-type ferrite bonded magnet was found to be better than that of a torque limiter prepared from an Sr-M-type ferrite bonded magnet, and the leakage magnetic flux decreased by $13 \%$.
\end{abstract}

Key Words: Sr-Zn-W-type hexagonal ferrite, bonded magnet, torque limiter, magnetic properties

\author{
$\mathrm{Sr}-\mathrm{Zn}$ 系W型フェライト粉末の磁気特性と \\ それらのボンド磁石のトルクリミッタへの応用 \\ 山元 洋・小泉 雄吾・山口 洋 \\ 明治大学理工学部, 川崎市多摩区東三田 1-1-1 （下214-8571）
}

1.はじめに

W型フェライト磁石 ${ }^{11}$ は, $\mathrm{M}$ 型フェライト磁石に比べ飽 和磁化が約 $10 \%$ 高く, 異方性磁界はほぼ等しいとの報告 がなされ, 次世代の異方性磁石材料として有用であること が指摘された。しかし，その作製方法には複雑な雰囲気制 御が必要とされ, 現在のところ工業化は難しいとされてい る. 近年種々の報告2) 12) により $\mathrm{Fe}^{2+} \mathrm{Zn}^{2+}$ で置換すること により大気中で容易にW型フェライトを作製することが できることが知られている.

本実験では, Sr-Zn系W型フェライト組成で, 大気中に て反応焼成を行うことにより作製したW型フェライト磁 石を粉砕した後, その粉末の磁気的, 物理的性質に及ぼす 影響ついて詳細に検討を行った. そして, これらW型フェ ライト粉末を用い, 射出成形ボンド磁石を作製し, 永久磁 石 $(\mathrm{Nd}-\mathrm{Fe}-\mathrm{B}$ 系圧縮成形ボンド磁石: $(\mathrm{BH}) \max =83.5$ $\mathrm{kJ} / \mathrm{m}^{3}, \mathrm{HcJ}=795.7 \mathrm{kA} / \mathrm{m}$ ）を用いた非接触型トルクリミ ッタ13)のヒステリシス磁石としての応用を試みた。

トルクリミッタは複写機を始めとした各種OA周辺機器 等の紙送り機構で多く使用されている. その用途は紙の重 送を防止することである. 非接触型トルクリミッタの動作 原理はヒステリシスモータ14) とほぼ同様であり, 永久磁石 と保磁力の小さい硬質磁性材料部分（ヒステリシス磁石と 呼称されている）の界磁とによってヒステリシストルク T が発生する。また，ヒステリシストルクの関係式15)は,

$$
\mathrm{T}=\alpha \times p \times V \mathrm{~m} \times E \mathrm{~h}
$$

$\{\mathrm{T}$ : ヒステリシストルク, $\alpha$ : 係数, $\mathrm{p}$ : 極対数（極数の 1/2), Vm : ヒステリシス磁石の体積, Eh : ヒステリシス 面積 (損) \}

で表される.この式から知られるように，ヒステリシスト ルクは極数，ヒステリシス面積（損）に比例する．本実験 では 12 極のものを作製した。

なお，本実験での現用のトルクリミッタへの応用には， トルクリミッタ外部に使用されているヒステリシス磁石 を, 飽和磁化が大きく保磁力が小さなものが比較的作製可 能なW型フェライトのボンド磁石に代替することを目的 とした. 現用のヒステリシス磁石（異方性 $\mathrm{Fe}-\mathrm{Cr}-\mathrm{Co}$ 系半硬 質磁性材料) ${ }^{15)}$ の保磁力約 $60 \mathrm{kA} / \mathrm{m}$ を目標の值に実験を行 い, 近い将来実用化されるであろうと思われる Sr-M型フェ ライトボンド磁石との比較検討を行ったので報告する.

\section{2. 実 験 方 法}

実験に用いた原材料は市販の試薬特級で, $\mathrm{SrCO}_{3}, \mathrm{ZnO}$ そして $\alpha-\mathrm{Fe}_{2} \mathrm{O}_{3}$ である。仕込み組成を $\mathrm{SrO} \cdot \mathrm{xZnO}$ ・ $(2-\mathrm{x}) \mathrm{FeO} \cdot 8 \mathrm{Fe}_{2} \mathrm{O}_{3}$ としxを $0.5,1.0,1.5,2.0$ と変化させ， 秤量は総量 $0.3 \mathrm{~kg}$ となるように行い, ボールミル (湿式法) にて混合を行った，得られた泥状試料を乾燥させた後，焼 成用試料としてプレス圧 $49 \mathrm{MPa}$ で $\phi 36 \mathrm{~mm} \times 7 \mathrm{~mm}$ の円 柱状に成形し, 大気中にて $1200 \sim 1350^{\circ} \mathrm{C} て ゙ ~ 4.0 \mathrm{~h}$ の反応焼 成を行った：引き続き，焼成試料を $150 \mu \mathrm{m}$ 以下に粗粉砕 した後, ステンレス製振動ミル (湿式法)を用いて $1.0 \sim 4.0$ 
$\mathrm{h}$ の微粉砕を行った. この試料を乾燥した後, 粉末試料を 得た. 得られた粉末試料を用いて等方性射出成形ボンド磁 石を作製した。なお、バインダーにはナイロン 12 を使用 した.

粉末試料の磁気特性, キュリー温度及び温度特性につい ては振動試料型磁力計 (VSM) で測定し, ボンド磁石の磁 気特性は直流自記磁束計で測定した。また， s $_{\text {s }}$ VSMを 用いて最大磁界 $20 \mathrm{kOe}$ で測定し，1/H2で外挿して求めた. 粉末の粒度及び形状については走査型電子顕微鏡（SEM） を用いて観察した. また, 結晶構造についてはFe管球を用 いて粉末X線回折法で検討した。トルクリミッタの特性の 測定にはトルク計, ガウスメータ（表面漏れ磁束の測定） を用いた。

また, 本実験のW型フェライトと比較を行ったSr-M型フ エライト磁石は, 組成を $\mathrm{SrO} \cdot 5.8 \mathrm{Fe}_{2} \mathrm{O}_{3}$ とし, 反応焼成条 件を $1180^{\circ} \mathrm{C}$ で $2.0 \mathrm{~h}$, 微粉砕を振動ボールミル（乾式法） で $100 \mathrm{~min}$ とし作製した。

\section{3. 実験結果ならびに考察}

\section{1 ボンド磁石用粉末の諸特性}

まず最初に, 大気中における反応焼成が及ぼす磁気特性 のうちW型フェライトの特徵を出すために, 特に飽和磁化 への影響について検討を行った. Table 1 は仕込み組成 $\mathrm{SrO} \cdot \mathrm{xZnO} \cdot(2-\mathrm{x}) \mathrm{FeO} \cdot 8 \mathrm{Fe}_{2} \mathrm{O}_{3}$ においてxを 0.5, 1.0, 1.5, 2.0 としたときの, $1200 \sim 1350^{\circ} \mathrm{C}$ 飽和磁化の值を表にま とめたものである. なお, 表中R.S.C.はReaction Sintering Conditionの略称である. いずれも反応焼成時間を $4.0 \mathrm{~h}$ と し, 大気中にて作製したものである. 表より組成の変化に より著しい $\sigma_{\mathrm{s}}$ の増減がみられた， $\mathrm{x}=2.0$ 組成においては $\sigma$ sは約 $90 \times 10^{-6} \mathrm{~Wb} \cdot \mathrm{m} / \mathrm{kg}$ にとどまった。また， $\mathrm{x}=0.5$ 組成においても反応焼成温度が $1350^{\circ} \mathrm{C}$ 以外では $\sigma \mathrm{s}$ は低い 值になった. $\mathrm{x}=1.0,1.5$ 組成では反応焼成温度が $1300^{\circ} \mathrm{C}$ 以上で良好な值が得られた. Fig. 1 はx $=1.0$ 組成の反応焼 成温度別のX線回折図形を示した図である. 図から分かる ように $1200,1250^{\circ} \mathrm{C} て ゙ \mathrm{~W}$ 相, $\mathrm{M}$ 相, $\mathrm{Fe}_{3} \mathrm{O}_{4}$ 相, $\alpha-\mathrm{Fe}_{2} \mathrm{O}_{3}$ 相 の回折線が見られ， $1300,1350^{\circ} \mathrm{C} て ゙ W$ 相単相となること

Table 1 Effect of the reaction sintering temperature on the saturation magnetization of $\mathrm{SrO} \cdot \mathrm{xZnO} \cdot(2-\mathrm{x}) \mathrm{FeO} \cdot 8 \mathrm{Fe}_{2} \mathrm{O}_{3}(\mathrm{x}=0.5,1.0,1.5,2.0)$ ferrites.

\begin{tabular}{|c|c|c|c|c|}
\hline \multirow{2}{*}{$\begin{array}{r}\mathrm{SrO} \cdot \mathrm{xZnO} \\
(2-\mathrm{x}) \mathrm{FeO} \cdot 8 \mathrm{Fe}_{2} \mathrm{O}_{3} \\
\left({ }^{\circ} \mathrm{C}\right)\end{array}$} & \multicolumn{4}{|c|}{$\sigma_{\mathrm{s}}\left(\times 10^{-6} \mathrm{~Wb} \cdot \mathrm{m} / \mathrm{kg}\right)$} \\
\hline & 1200 & 1250 & 1300 & 1350 \\
\hline$x=0.5$ & 71.6 & 77.7 & 91.3 & 100.5 \\
\hline$x=1.0$ & 85.8 & 95.9 & 102.2 & 105.1 \\
\hline$x=1.5$ & 89.4 & 95.0 & 99.6 & 101.2 \\
\hline$x=2.0$ & 89.8 & 90.0 & 90.1 & 91.7 \\
\hline
\end{tabular}
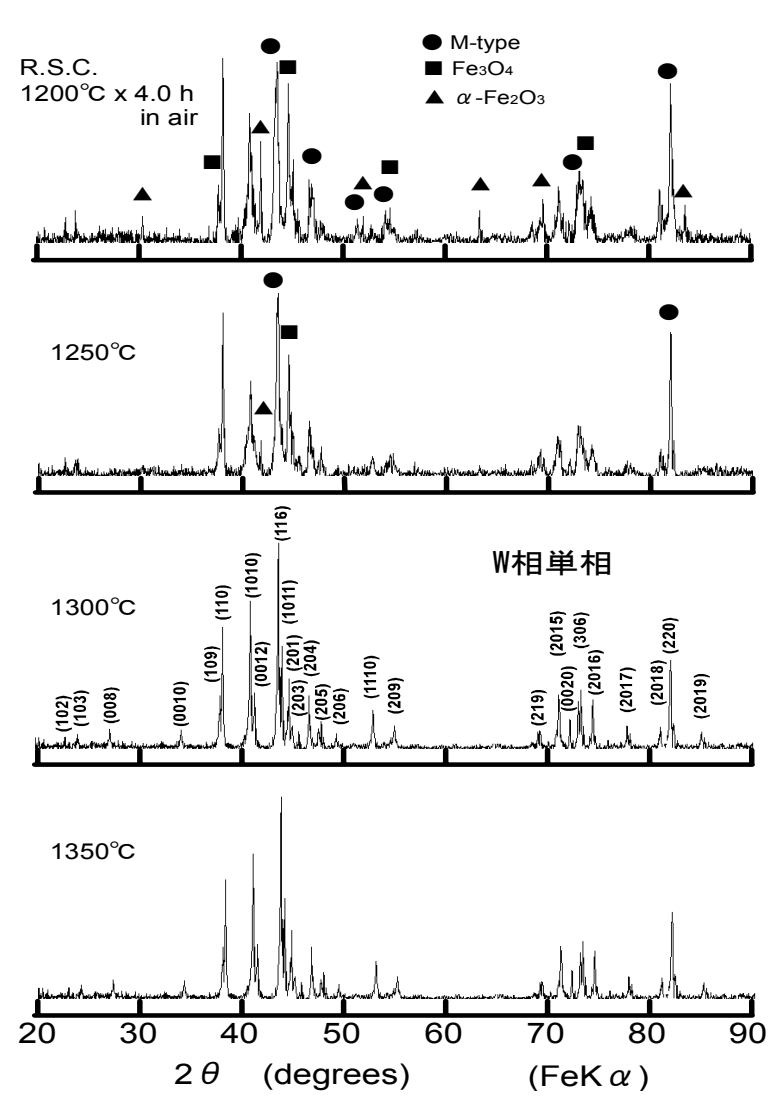

Fig. $1 \mathrm{X}$-ray diffraction patterns of $\mathrm{SrO} \cdot \mathrm{ZnO}$. $\mathrm{FeO} \cdot 8 \mathrm{Fe}_{2} \mathrm{O}_{3}$ ferrite.

Table 2 Phase analyses of $\mathrm{SrO} \cdot \mathrm{xZnO} \cdot(2-\mathrm{x}) \mathrm{FeO} \cdot$ $8 \mathrm{Fe}_{2} \mathrm{O}_{3}(\mathrm{x}=0.5,1.0,1.5,2.0)$ ferrites.

\begin{tabular}{c|c|c|c|c}
\hline \multirow{2}{*}{$\begin{array}{c}\mathrm{SrO} \cdot \mathrm{xZnO} \cdot \\
(2-\mathrm{x}) \mathrm{FeO} \cdot 8 \mathrm{Fe}_{2} \mathrm{O}_{3}\end{array}$} & \multicolumn{4}{|c}{ Reaction sintering temperature $\left({ }^{\circ} \mathrm{C}\right)$} \\
\cline { 2 - 5 } & 1200 & 1250 & 1300 & 1350 \\
\hline $\mathrm{x}=0.5$ & $\mathrm{~W}, \mathrm{M}, \mathrm{S}, \alpha$ & $\mathrm{W}, \mathrm{M}, \mathrm{S}, \alpha$ & $\mathrm{W}, \mathrm{M}, \alpha$ & $\mathrm{W}$ \\
\hline $\mathrm{x}=1.0$ & $\mathrm{~W}, \mathrm{M}, \mathrm{S}, \alpha$ & $\mathrm{W}, \mathrm{M}, \mathrm{S}, \alpha$ & $\mathrm{W}$ & $\mathrm{W}$ \\
\hline $\mathrm{x}=1.5$ & $\mathrm{~W}, \mathrm{M}, \mathrm{S}$ & $\mathrm{W}, \mathrm{M}, \mathrm{S}$ & $\mathrm{W}$ & $\mathrm{W}$ \\
\hline $\mathrm{x}=2.0$ & $\mathrm{~W}$ & $\mathrm{~W}$ & $\mathrm{~W}, \mathrm{~S}$ & W,S \\
\hline
\end{tabular}

W: W-type $\quad$ M: M-type $\quad \mathrm{S}^{-\mathrm{Fe}_{3} \mathrm{O}_{4}} \quad \alpha: \alpha-\mathrm{Fe}_{2} \mathrm{O}_{3}$

が分かった.さらに他の組成においても同様の実験，検討 を行い, その結果を Table 2 にまとめた. W 相単相が得ら れたのは $\mathrm{x}=0.5$ 組成では $1350^{\circ} \mathrm{C}$ のき, $\mathrm{x}=1.5$ 組成では $1300,1350^{\circ} \mathrm{C}$ のをき, $\mathrm{x}=2.0$ 組成では $1200,1250^{\circ} \mathrm{C}$ のときであることが分かった. 以上より，これら Table 1, Fig. 1, Table 2 から, より低い反応焼成温度で $\mathrm{W}$ 相単相 となり, 高い飽和磁化值を得ることができた $\mathrm{x}=1.0$ 組成 で, 反応焼成条件を $1300^{\circ} \mathrm{C}$ で $4.0 \mathrm{~h}$ を作製条件とし以後実 験を行った。なお， $1350^{\circ} \mathrm{C}$ の方が飽和磁化值は高いが，工 業的な視野から $1300^{\circ} \mathrm{Cを}$ 選択した。

Fig. 2 は微粉砕後に得られた試料の磁気特性を示した図 である. 粉砕時間が延びるにつれ $\sigma_{\mathrm{s}}$ は減少，保磁力は上昇 する傾向を示した．本実験では現用のヒステリシス磁石の 保磁力である約 $60 \mathrm{kA} / \mathrm{m}$ を目標としたので, その值にもつ とも近かった粉砕時間 $2.0 \mathrm{~h}$ 最適粉砕時間とした.

Fig. 3 はボンド磁石の作製に用いる粉砕時間 $2.0 \mathrm{~h}$ の粉 
末試料の X 線回折図形である.ほぼ W 相単相が得られた. なお，図中 P.T.は Pulverizing Time の略称である.

Table 3 は微粉砕後に得られた試料を, 一般に射出成形 ボンド磁石を作製する前段階として行われる $98 \mathrm{MPa}$ の圧 カでプレスした後に得られた圧粉体の密度を示す. 微粉砕 時間が延びるにつれ密度は減少する傾向を示した。これは， これら粉末が微細になっているものと思われる. 磁気特性 の目標值が得られた粉砕時間 $2.0 \mathrm{~h}$ での圧粉体密度は 2.77 $\mathrm{Mg} / \mathrm{m}^{3}$ と若干低かった。

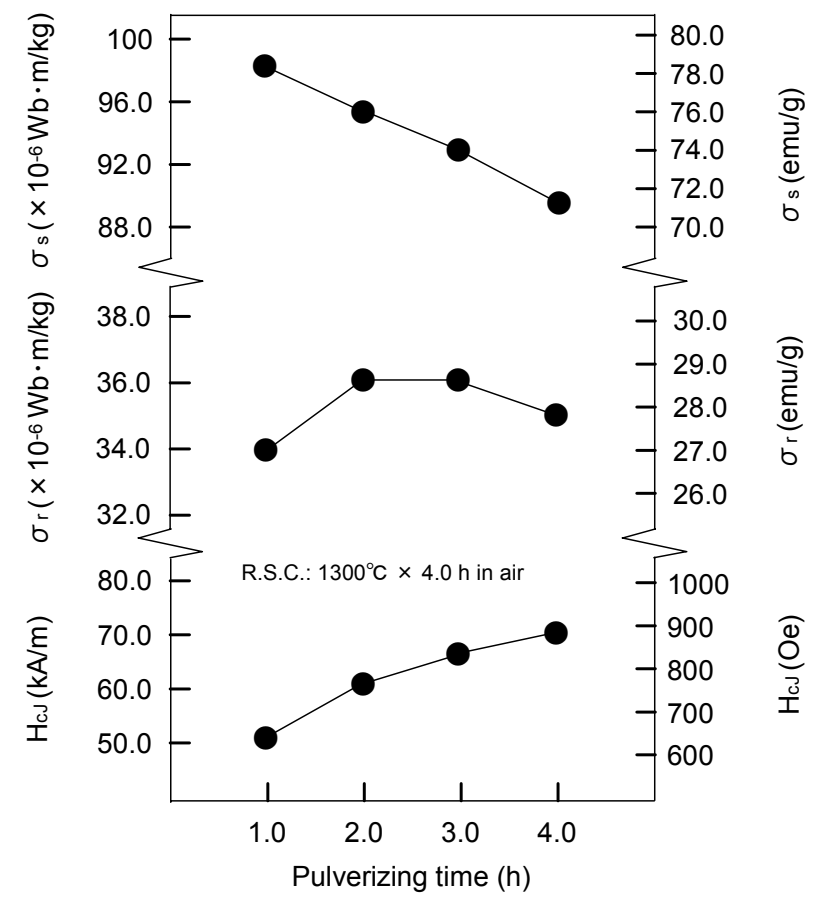

Fig. 2 Effect of the pulverizing time on the magnetic properties of $\mathrm{SrO} \cdot \mathrm{ZnO} \cdot \mathrm{FeO} \cdot 8 \mathrm{Fe}_{2} \mathrm{O}_{3}$ ferrite.
Table 3 Effect of the pulverizing time on the density of green compacts of $\mathrm{SrO} \cdot \mathrm{ZnO} \cdot \mathrm{FeO}$. $8 \mathrm{Fe}_{2} \mathrm{O}_{3}$ ferrite.

(Compressive force: $98.0 \mathrm{MPa}$ )

\begin{tabular}{c|c|c|c|c}
\hline $\begin{array}{c}\text { Pulverizing } \\
\text { time }(\mathrm{h})\end{array}$ & 1.0 & 2.0 & 3.0 & 4.0 \\
\hline $\begin{array}{c}\text { Density } \\
\left(\mathrm{Mg} / \mathrm{m}^{3}\right)\end{array}$ & 2.82 & 2.77 & 2.74 & 2.73 \\
\hline
\end{tabular}

次に，この粉末試料の温度依存性，およびキュリー温度 の測定, SEMによる粉末の観察, 粉末の化学分析を行った. Fig. 4 は最適作製条件で作製した粉末試料の $\sigma$-T曲線であ る.なお測定はVSMを用いて印加磁界零で行った。この図 よりキュリー温度 $\mathrm{T}_{\mathrm{C}}$ キ $425^{\circ} \mathrm{C}$ であることが分かった。これ はW型フェライトの雰囲気制御した值 $\left.{ }^{16)}, 17\right)$ より $50^{\circ} \mathrm{C}$ 以上 低い值となっている.

Fig. 5 に同じく最適作製条件にて作製した粉末試料の磁 束の温度依存性を示す. 測定にはVSMを用いて行った。測 定温度範囲は $20 \sim 120^{\circ} \mathrm{C}$ と，そのときの磁束の可逆温度 係数を求めたところ， $\alpha(\phi)=-0.18 \% /{ }^{\circ} \mathrm{C}$ であり，一般的 な $\mathrm{Sr}-\mathrm{M}$ 型フェライト磁石の温度係数 ${ }^{18)}$ とほぼ同じであっ た。

Fig. 6 に最適作製条件で作製した粉末試料のSEM写真 を示す.この写真より約 200 個の粒子の径を測定し平均粒 子径を求めたところ, $0.85 \mu \mathrm{m}$ であった。この平均粒子径 はフェライトの単磁区粒子径19)に近い值である.

以上の結果と化学分析の結果をTable 4 にまとめた. 本 実験においてW相単相が得られ，トルクリミッタに使用さ れているヒステリシス磁石の保磁力である $60 \mathrm{kA} / \mathrm{m}$ に最 も近かった試料の作製条件は，仕込み組成 $\mathrm{SrO} \cdot \mathrm{ZnO} \cdot \mathrm{FeO}$. $8 \mathrm{Fe}_{2} \mathrm{O}_{3}$ において反応焼成を大気中にて $1300^{\circ} \mathrm{C} て ゙ 4.0 \mathrm{~h}$ の 条件で行い，ステンレス製振動ミル（湿式法）にて $2.0 \mathrm{~h}$ の微粉砕を行ったものであり，そのときの磁気特性は $\sigma \mathrm{s}=$ $95.5 \times 10^{-6} \mathrm{~Wb} \cdot \mathrm{m} / \mathrm{kg}, \mathrm{H}_{\mathrm{cJ}}=60.5 \mathrm{kA} / \mathrm{m}$ であった.また， 化学分析值は仕込み組成にほぼ近く, 化学量論組成に近い 值であった。

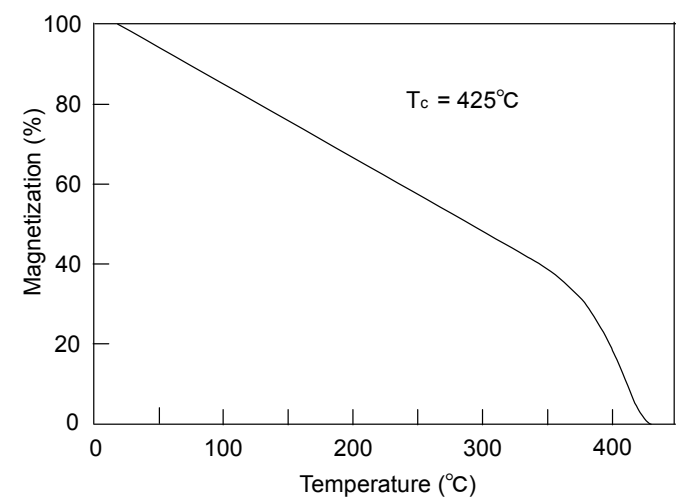

Fig. $4 \quad \sigma-\mathrm{T}$ curve of $\mathrm{SrO} \cdot \mathrm{ZnO} \cdot \mathrm{FeO} \cdot 8 \mathrm{Fe}_{2} \mathrm{O}_{3}$ ferrite powders. 


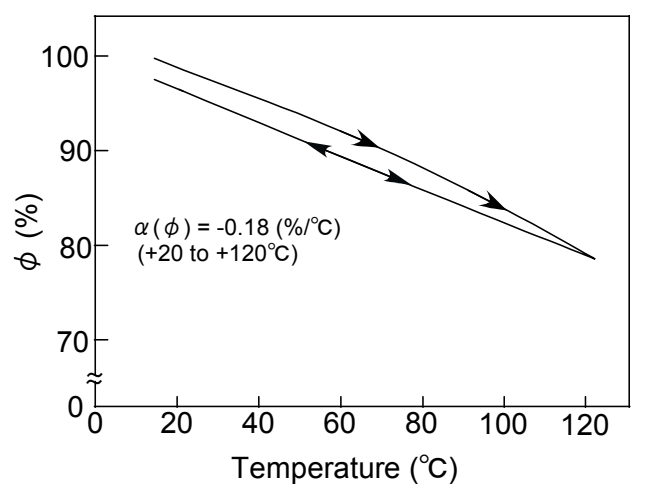

Fig. 5 Temperature dependence curve of the flux loss of $\mathrm{SrO} \cdot \mathrm{ZnO} \cdot \mathrm{FeO} \cdot 8 \mathrm{Fe}_{2} \mathrm{O}_{3}$ ferrite powders.

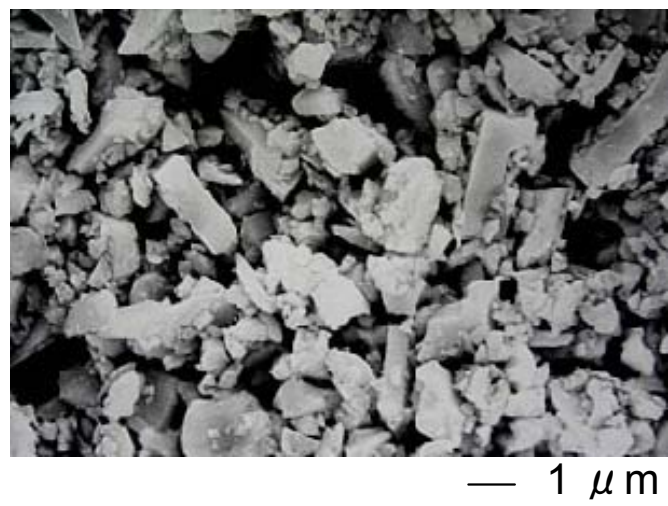

Average particle size: $0.85(\mu \mathrm{m})$

Fig. $6 \mathrm{SEM}$ photograph of $\mathrm{SrO} \cdot \mathrm{ZnO} \cdot \mathrm{FeO} \cdot 8 \mathrm{Fe}_{2} \mathrm{O}_{3}$ ferrite powders.

Table 4 Some properties of $\mathrm{SrO} \cdot \mathrm{ZnO} \cdot \mathrm{FeO} \cdot 8 \mathrm{Fe}_{2} \mathrm{O}_{3}$ ferrite.

\begin{tabular}{|c|c|c|}
\hline \multicolumn{3}{|c|}{$\begin{array}{r}\mathrm{Sr}^{2+}{ }_{0.93} \mathrm{Zn}^{2+}{ }_{0.93} \mathrm{Fe}^{2+}{ }_{1.02} \mathrm{Fe}^{3+}{ }^{16.07} \mathrm{O}_{27} \\
\text { (analyzed value) }\end{array}$} \\
\hline \multirow{2}{*}{$\begin{array}{l}\text { Magnetic } \\
\text { properties }\end{array}$} & $\sigma_{\mathrm{s}}\left(\times 10^{-6} \mathrm{~Wb} \cdot \mathrm{m} / \mathrm{kg}\right)$ & 95.5 \\
\hline & $\mathrm{H}_{\mathrm{cJ}}(\mathrm{kA} / \mathrm{m})$ & 60.5 \\
\hline Curie temperature & $\mathrm{T}_{\mathrm{c}}\left({ }^{\circ} \mathrm{C}\right)$ & 425 \\
\hline $\begin{array}{l}\text { Average } \\
\text { particle size }\end{array}$ & $(\mu \mathrm{m})$ & 0.85 \\
\hline $\begin{array}{l}\text { Density of } \\
\text { green compact } \\
\text { (compressive force: } 98 \mathrm{MPa} \text { ) }\end{array}$ & $\left(\mathrm{Mg} / \mathrm{m}^{3}\right)$ & 2.77 \\
\hline
\end{tabular}

\section{2 ボンド磁石の磁気特性およびトルクリミッタの特性}

次に前述の粉末を用いたコンパウンドを, 磁場配向させ ずに射出成形ボンド磁石を作製した。また，バインダーに はナイロン 12 を用いた. Table 5 にフェライト充填率を $88.0 \mathrm{wt} \%$ としたときの本実験で作製したW型フェライト ボンド磁石と，トルクリミッタへの応用を考慮し， M型フ
エライトとしては比較的小さな保磁力を有する平均粒子 径が約 $1.4 \mu \mathrm{m}$ であるSr系M型フェライト粉末から作製し たボンド磁石の磁気特性との比較を行った．表から知られ るようにM型ボンド磁石に比べW型ボンド磁石の残留磁 束密度 $\mathrm{B}_{\mathrm{r}}$ は $11 \%$ ，飽和磁化 $\mathrm{J}_{\mathrm{s}}$ は $26 \%$ 高い值であった。

Fig. 7 にトルクリミッタの概観図及び分解図を示寸。本 実験で作製した W 型フェライトボンド磁石は分解図の Sr-Zn 系ボンド磁石と示している部分に使用した。また， その大きさは内径 $14.60 \mathrm{~mm}$, 外径 $18.20 \mathrm{~mm}$, 長さ 18.18 $\mathrm{mm}$ である。

Table 6 では上記の $\mathrm{W}$ 型フェライトボンド磁石と $\mathrm{M}$ 型 フェライトボンド磁石を用いて作製したトルクリミッタ の特性を比較した. W 型フェライトボンド磁石を用いて作 製したトルクリミッタは, M 型フェライトボンド磁石で作 製したトルクリミッタに比べ，トルクは若干向上した。こ れは $\mathrm{W}$ 型フェライトは $\mathrm{M}$ 型フェライトより飽和磁化が大 きいため，ヒステリシス損が大きくなり，ヒステリシスト ルクが上昇したためと考えられる。漏れ磁束は $13 \%$ 減少 し，有効磁束の増加により本来のヒステリシス損がそこな われることなく, 大きな高効率な動作をするトルクリミッ タを作製することができた.

Table 5 Magnetic properties of W-type ferrite and M-type ferrite bonded magnets.

\begin{tabular}{c|c|c}
\multicolumn{3}{c}{$\begin{array}{c}\text { Concentration of magnetic powder } \\
\text { in bonded magnets: 88.0 wt\% }\end{array}$} \\
\hline Magnetic properties & W-type ferrite & M-type ferrite \\
\hline $\mathrm{Br}(\mathrm{mT})$ & 140 & 126 \\
\hline $\mathrm{H}_{\mathrm{cJ}}(\mathrm{kA} / \mathrm{m})$ & 65.3 & 103.5 \\
\hline $\mathrm{Js}_{\mathrm{s}}(\mathrm{mT})$ & 281 & 223 \\
\hline$(\mathrm{BH})_{\max }\left(\mathrm{kJ} / \mathrm{m}^{3}\right)$ & 2.15 & 2.31 \\
\hline
\end{tabular}
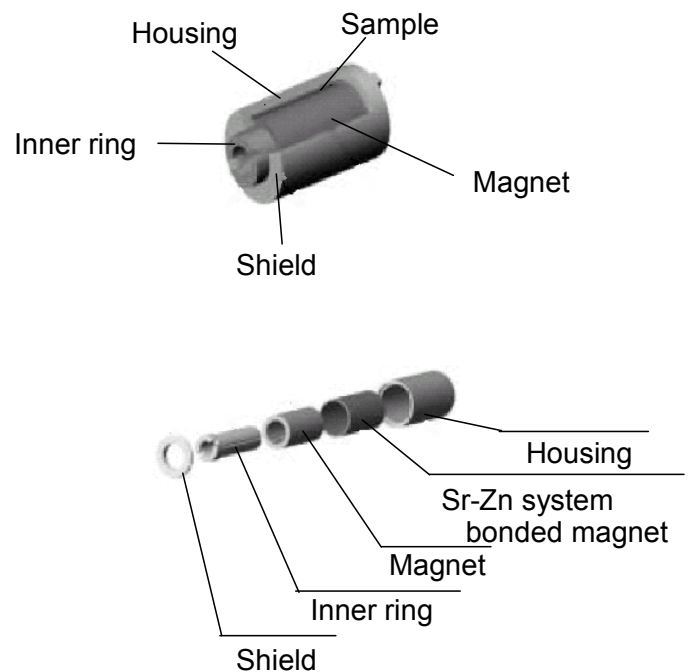

Fig. 7 Structure and components of a non-contact torque limiter. 
Table 6 Torque and leakage flux of torque limiters prepared from W-type ferrite and M-type ferrite bonded magnets.

\begin{tabular}{c|c|c}
\hline Using powder & W-type ferrite & M-type ferrite \\
\hline Torque properties & 2.7 & 2.6 \\
\hline Torque $\left(\times 10^{-2} \mathrm{~N} \cdot \mathrm{m}\right)$ & 59.9 & 68.8 \\
\hline
\end{tabular}

\section{4. 結 言}

本実験の結果をまとめると以下のようになる.

1) $\mathrm{SrO} \cdot \mathrm{xZnO} \cdot(2-\mathrm{x}) \mathrm{FeO} \cdot 8 \mathrm{Fe}_{2} \mathrm{O}_{3}$ (仕込み組成) におい て, $\mathrm{x}$ の值の変化に伴い, 大気中にて反応焼成を 1200 $\sim 1350^{\circ} \mathrm{C}$ 温度範囲で行ったところ, $\mathrm{W}$ 相単相の得 られる温度が組成により異なることが知られた。

2) $\mathrm{SrO} \cdot \mathrm{ZnO} \cdot \mathrm{FeO} \cdot 8 \mathrm{Fe}_{2} \mathrm{O}_{3}$ (仕込み組成)において平均 粒子径が $0.85 \mu \mathrm{m}$ のとき, 磁気特性は $\sigma \mathrm{s}=95.5 \times$ $10^{-6} \mathrm{~Wb} \cdot \mathrm{m} / \mathrm{kg}, \mathrm{H}_{\mathrm{cJ}}=60.5 \mathrm{kA} / \mathrm{m}$ となった。 この粉 末を用いて射出成形ボンド磁石を作製したところ $\mathrm{B}$ r $=140 \mathrm{mT}, \mathrm{J}_{\mathrm{s}}=281 \mathrm{mT}, \mathrm{H}_{\mathrm{cJ}}=65.3 \mathrm{kA} / \mathrm{m}$ となり $\mathrm{Sr}$ 系 $\mathrm{M}$ 型フェライト(平均粒子径: $1.4 \mu \mathrm{m}$ )のボンド磁 石に比べBr

3） W型フェライトのボンド磁石を用いて作製したトル クリミッタはトルク $\mathrm{T}=2.7 \times 10^{-2} \mathrm{~N} \cdot \mathrm{m}$, 漏孔磁束 L.F. $=59.9 \mathrm{mT}$ となり, $\mathrm{Sr}$ 系M型フェライトのボン ド磁石を用いて作製したトルクリミッタに比べ，若 干トルクが上昇した.また, 漏れ磁束は $13 \%$ 減少し, 有効磁束の増加により, ヒステリシス磁石のヒステ リシス損がそこなわれることがなく，高効率のトル クリミッタが作製できた。

\section{References}

1) F. K. Lotgering, P. H. G. M. Vromans and M. A. H. Huyberts: J. Appl. Phys., 515913 (1980).

2) R.O. Savage and A. Tauber: J. Am.Ceram. Soc., 47, 13 (1964).

3) G. Albanese, M. Carbucicchio and G. Asti: Appl. Phys., 11, 81 (1976).

4) L. G. Van Uitert, M. H. Read and F. J. Schnettler: J. Appl. phys., 28, 280 (1957).

5) F. K. Lotgering, U. Enz and J. Smit: Phillips Res. Rep., 16, 441 (1961).

6) H. Graetsch. F. Haberey. R. leckebusch. M. S. Rösenberg and K. Sahl: IEEE Trans. Magn., 20 No.3, 495 (1984).

7) L. R. Hodges Jr. and G. R. Harrisonः J. Am. Ceram. Soc., 47, 601 (1964).

8) T. Besagni, A. Deriu, F. Licci, L. Pareti and S. Rinaldi: IEEE Trans. Magn., 17 No.6, 2636 (1981).

9) F. Licci, L. Pareti and S. Rinaldi: J. Appl. Phys., 17, 2636 (1981).

10) H. Kojima, C. Miyakawa, T. Sato and K. Goto: J. Appl. Phys., 24, 51 (1985).

11) T. Besagni, A. Deriu, F. Licci and S. Rinaldi: J. Magn. Magn. Mat., 31-34, 791 (1983).

12) H. Yamamoto, M. Nagakura and H. Ono: IEEE Trans. Magn., 24 No.1, 598 (1988).

13) K. Shinohara: Origin Technical Journal, No.67, II -3 (2004).

14) Y. Kanno: Mota Gijutu Jituyo Handobukku (in Japanese), p. 110 (Nikkankougyo ShinbunSha, Tokyo, 2001).

15) H. Hayashi, H. Sakamoto, Y. Kimura: Kokai Tokkyo Koho JP 2000-179566(2000).

16) H. Yamamoto, Y. Sakai, and M. Ohmura: J. Magn. Soc. Jpn., 26 No.4, 358 (2002).

17) M. Ohmura and H. Yamamoto: IEEE Trans. Magn., 40 No.3, 1695 (2004).

18) T. Hiraga, K. Okutani, and T. Ojima: Ferrite, p. 140 (Maruzen Shuppan, Tokyo, 1986).

19) E. P. Wohlfarth: FERROMAGNETIC MATERIALS VOLUME 3, p. 335 (NORTH-HOLLAND Publishing Company, Amsterdam, 1982).

2005 年 10 月 19 日受理, 2005 年 12 月 16 日採録 